\title{
Desulfotomaculum thermobenzoicum subsp. thermosyntrophicum subsp. nov., a thermophilic, syntrophic, propionate-oxidizing, spore-forming bacterium
}

Laboratory of

Microbiology, Wageningen

University, H. van

Suchtelenweg 4,

6307 CT Wageningen,

The Netherlands

\author{
Caroline M. Plugge, Melike Balk and Alfons J. M. Stams \\ Author for correspondence: Caroline M. Plugge. Tel: +31 317 482105. Fax: + 31317483829. \\ e-mail:caroline.plugge@algemeen.micr.wag-ur.nl
}

From granular sludge from a laboratory-scale upflow anaerobic sludge bed reactor operated at $55^{\circ} \mathrm{C}$ with a mixture of volatile fatty acids as feed, a novel anaerobic, moderately thermophilic, syntrophic, spore-forming bacterium, strain TPO, was enriched on propionate in co-culture with Methanobacterium thermoautotrophicum Z245. The axenic culture was obtained by using pyruvate as the sole source of carbon and energy. The cells were straight rods with pointed ends and became lens-shaped when sporulation started. The cells were slightly motile. The optimum growth temperature was $55^{\circ} \mathrm{C}$ and growth was possible between 45 and $62{ }^{\circ} \mathrm{C}$. The $\mathrm{pH}$ range for growth of strain TPO was 6-8, with an optimum at pH 7-7.5. Propionate was converted to acetate, $\mathrm{CO}_{2}$ and $\mathrm{CH}_{4}$ by a co-culture of strain TPO with Methanobacterium thermoautotrophicum Z245. In pure culture, strain TPO could grow fermentatively on benzoate, fumarate, $\mathrm{H}_{2} / \mathrm{CO}_{2}$, pyruvate and lactate. Sulphate could serve as inorganic electron acceptor when strain TPO was grown on propionate, lactate, pyruvate and $\mathrm{H}_{2} / \mathrm{CO}_{2}$. The $\mathrm{G}+\mathrm{C}$ content was $53.7 \mathrm{~mol} \%$. Comparison of $16 \mathrm{~S}$ rDNA sequences revealed that strain TPO is related to Desulfotomaculum thermobenzoicum (98\%) and Desulfotomaculum thermoacetoxidans (98\%). DNA-DNA hybridization revealed $88.2 \%$ reassociation between strain TPO and $D$. thermobenzoicum and $83.8 \%$ between strain TPO and $D$. thermoacetoxidans. However, both organisms differ physiologically from strain TPO and are not capable of syntrophic propionate oxidation. It is proposed that strain TPO should be classified as new subspecies of $D$. thermobenzoicum as $D$. thermobenzoicum subsp. thermosyntrophicum.

Keywords: Desulfotomaculum thermobenzoicum subspecies thermosyntrophicum subsp. nov., propionate oxidation, syntrophy, interspecies hydrogen transfer

\section{INTRODUCTION}

The methanogenic degradation of complex organic acids is brought about via a complex food chain, which ultimately ends up as $\mathrm{CH}_{4}, \mathrm{CO}_{2}$ and $\mathrm{NH}_{4}^{+}$(Zehnder, 1978; Zeikus, 1983). Propionate is an important intermediate in this conversion. To convert this compound completely to methane and $\mathrm{CO}_{2}$, different

The GenBank/EMBL/DDBJ accession number for the $16 \mathrm{~S}$ rDNA sequence of strain TPO is AY007190. physiological groups of micro-organisms are needed (Stams, 1994; Schink, 1997). Propionate is oxidized by acetogenic bacteria to acetate and $\mathrm{CO}_{2}$, whereas reducing equivalents are released as $\mathrm{H}_{2}$ and/or formate. The energetics of this reaction are highly unfavourable and are only possible when an external sink is present for the removal of $\mathrm{H}_{2}$ and/or formate. Methanogenic archaea usually serve as hydrogen- and formate-scavengers in syntrophic co-cultures with propionate oxidizers.

Several mesophilic, syntrophic propionate-oxidizing cultures have been described previously. Syntropho- 
bacter wolinii (Boone \& Bryant, 1980) was the first strain described. Other examples of syntrophic cultures are Syntrophobacter pfennigii and Syntrophobacter fumaroxidans (Wallrabenstein et al., 1995; Harmsen et al., 1998). These Syntrophobacter species are phylogenetically related and belong to a physiological heterogeneous group of sulphate-reducers. In the presence of sulphate, Syntrophobacter strains all couple propionate oxidation to sulphate reduction. Recently, Liu et al. (1999) described a syntrophic propionate-degrading organism, Smithella propionica. This organism is phylogenetically more related to syntrophic benzoate-degraders such as Syntrophus buswellii.

To date, very little has been known about thermophilic syntrophic propionate degradation. Desulfotomaculum thermocisternum was described as being capable of syntrophic growth on propionate in co-culture with a methanogen (Nilsen et al., 1996). Imachi et al. (2000) described the enrichment and phylogenetic position of a moderate thermophilic bacterium, strain SI, which can grow syntrophically on propionate.

A thermophilic consortium enriched by us on propionate (Stams et al., 1992) was able to degrade pyruvate and lactate without the presence of methanogens, indicating that the propionate-oxidizing bacterium was able to grow by fermentation. In this paper, we describe the isolation and characterization of a novel thermophilic, spore-forming, syntrophic, propionate-oxidizing bacterium, strain TPO, from that enrichment culture.

\section{METHODS}

Organisms, cultivation and isolation procedures. Strain TPO was isolated from an enrichment culture originating from thermophilic, anaerobic, granular sludge (Stams et al., 1992). D. thermocisternum (DSM 10259 ${ }^{\mathrm{T}}$ ) and Desulfotomaculum thermobenzoicum (DSM 6193 ${ }^{\mathrm{T}}$ ) were kindly provided by H. Goorissen, University of Groningen, The Netherlands. Methanobacterium thermoautotrophicum Z245 (DSM 3720) and Desulfotomaculum thermoacetoxidans (DSM 5813 ${ }^{\mathrm{T}}$ ) were obtained from the Deutsche Sammlung von Mikroorganismen und Zellkulturen GmbH (DSMZ, Braunschweig, Germany).

A bicarbonate-buffered anaerobic medium previously described by Stams et al. (1992) was used for the cultivation of all strains. Substrates were added from sterile anaerobic stock solutions to a final concentration of $20 \mathrm{mM}$ (unless otherwise stated). Occasionally yeast extract $(0 \cdot 02 \%, \mathrm{w} / \mathrm{v})$ was added to stimulate growth. For isolation of strain TPO, a direct dilution method was used in liquid medium supplemented with $20 \mathrm{mM}$ pyruvate as the sole source of carbon and energy, followed by dilution in soft agar media containing $0.75 \%$ agar. Purity was checked by light microscopy and growth in soft agar media.

For syntrophic growth tests, $1 \%$ strain TPO, Desulfotomaculum thermoacetoxidans, $D$. thermobenzoicum or $D$. thermocisternum were inoculated in hydrogen-pregrown cultures of Methanobacterium thermoautotrophicum Z245. Prior to inoculation, the gas phase of these bottles was changed to $180 \mathrm{kPa} \mathrm{N} \mathrm{N}_{2} / \mathrm{CO}_{2}(80: 20, \mathrm{v} / \mathrm{v})$ and $20 \mathrm{mM}$ propionate was added.

Determination of growth parameters. The temperature optimum was determined over a temperature range of $30-75^{\circ} \mathrm{C}$ in a bicarbonate-buffered medium containing $20 \mathrm{mM}$ pyruvate. The $\mathrm{pH}$ optimum was tested in basal medium containing $\mathrm{KH}_{2} \mathrm{PO}_{4}\left(0 \cdot 15 \mathrm{~g} \mathrm{l}^{-1}\right)$, instead of sodium bicarbonate, and $20 \mathrm{mM}$ pyruvate. The $\mathrm{pH}$ values of the medium containing $20 \mathrm{mM}$ pyruvate were adjusted with $\mathrm{NaOH}$ or $\mathrm{HCl}$. In this case, an $\mathrm{N}_{2}$ atmosphere was applied. Duplicate bottles were incubated at $55^{\circ} \mathrm{C}$ over a $\mathrm{pH}$ range of 4.5-9.5, and the time course of acetate production was measured.

Utilization of substrates by strain TPO in pure culture and in co-culture with Methanobacterium thermoautotrophicum Z245 was determined by monitoring growth, substrate depletion and product formation. All these incubations were performed at $55^{\circ} \mathrm{C}$ and $\mathrm{pH} 7$. The effect of electron acceptors on the growth of strain TPO was tested in basal medium with $20 \mathrm{mM}$ propionate.

Morphological characterization. All methods used for the morphological characterization of strain TPO were as described previously (Plugge et al., 2000). Transmission electron microscopy was performed as described previously (Plugge et al., 2000).

$\mathbf{G}+\mathbf{C}$ content. Isolation and purification of genomic DNA was carried out according to Marmur (1961). The $\mathrm{G}+\mathrm{C}$ content of the DNA was determined by thermal denaturation, as described by Owen et al. (1969).

16S rDNA sequence analysis. DNA was extracted from strain TPO as previously described by Zoetendal et al. (1998). A PCR was performed with the bacterial primers $7 \mathrm{f}$ and $1510 \mathrm{r}$ by using the Taq DNA polymerase kit from Life Technologies to amplify the bacterial $16 \mathrm{~S}$ rDNA. The PCR products were purified with the Qiaquick PCR purification kit (Qiagen) according to the manufacturer's instructions. Primers 515r, 1100r (Lane, 1991) and 968f (Nübel et al., 1996) labelled with Infrared Dye 41 (MWG-Biotech) were used for sequencing. The sequences were automatically analysed on a LI-COR DNA sequencer (4000L) and corrected manually. Phylogenetic analysis and tree construction were performed with the programs of the ARB software package (Strunk \& Ludwig, 1991). The tree is based on the results of distance matrix analysis including only those sequence positions that share the same nucleotides in at least $50 \%$ of sequences from relevant members of Grampositive bacteria (Felsenstein, 1982). FASTA homology searches with sequences of the EMBL and GenBank DNA databases were performed and the results were compared with those obtained with the ARB programs.

DNA-DNA hybridization experiments. DNA-DNA hybridization was performed with strain TPO, D. thermobenzoicum DSM $6193^{\mathrm{T}}, D$. thermoacetoxidans DSM 5813 ${ }^{\mathrm{T}}$ and $D$. thermocisternum DSM $10259^{\mathrm{T}}$ at the DSMZ. DNA was isolated by chromatography on hydroxyapatite according to the procedure of Cashion et al. (1977). DNA-DNA hybridization was carried out as described by DeLey et al. (1970), with modifications as described by Huß et al. (1983) and Escara \& Hutton (1980) using a Gilford model 2600 spectrophotometer equipped with a Gilford model 2527-R thermoprogrammer and plotter. Renaturation rates were computed with the TRANSFER.BAS program of Jahnke (1992).

Preparation of cell-free extracts. Cells of strain TPO in coculture with Methanobacterium thermoautotrophicum strain 
Z245 grown on propionate and in pure culture grown on $\mathrm{H}_{2} / \mathrm{CO}_{2}$ plus sulphate were centrifuged $(23000 \mathrm{~g}, 10 \mathrm{~min}$, $\left.4{ }^{\circ} \mathrm{C}\right)$. The cell pellet was suspended in $0 \cdot 1 \mathrm{M}$ Tris buffer $(\mathrm{pH}$ 8.0) containing $0.4 \mathrm{mg} \mathrm{Na}{ }_{2}$ EDTA per $\mathrm{ml}$ and $50 \mu \mathrm{g}$ lysozyme $\mathrm{ml}^{-1}$ as described by Wofford et al. (1986). Cells were disrupted by ultrasonic disintegration $(4 \times 30 \mathrm{~s}, 30 \mathrm{kHz})$. Cell debris was removed by centrifugation $(8000 \mathrm{~g}, 15 \mathrm{~min}$, $4{ }^{\circ} \mathrm{C}$ ) and the supernatant was stored anaerobically at $4{ }^{\circ} \mathrm{C}$. Protein concentrations were determined by the method of Bradford (1976), and bovine serum albumin was used as the standard.

Enzyme assays. Enzyme assays were carried out anaerobically at $55^{\circ} \mathrm{C}$ by using a Hitachi U-2010 UV-VIS spectrophotometer. Cuvettes $(1 \mathrm{ml})$ were closed with rubber stoppers and flushed with $\mathrm{N}_{2}$. Hydrogenase (EC 1.12.1.2) and pyruvate dehydrogenase (EC 1.2.4.1) were assayed with methyl viologen as the electron acceptor according to Odom \& Peck (1981). Fumarase (EC 4.2.1.2), malate dehydrogenase (NAD-dependent, EC 1.1.1.37, and NADH-dependent, EC 1.1.1.82), methylmalonyl-CoA:pyruvate transcarboxylase (EC 2.1.3.1), phosphotransacetylase (EC 2.3.1.8) and succinate dehydrogenase (EC 1.3.99.1) activities were assayed according to Stams et al. (1984). Propionate kinase and acetate kinase (EC 2.7.2.1) activities were determined as described by Aceti \& Ferry (1988). Carbonmonoxide dehydrogenase (EC 1.2.99.2) and 2-oxoglutarate: methylviologen oxidoreductase (EC 1.2.7.3) activities were measured according to Schauder et al. (1986).

To calculate the specific activities of enzymes of the propionate-oxidizing organisms in cell-free extracts of cocultures, a correction was made for the biomass produced by the methanogen, using the molar growth yield $[2 \cdot 2 \mathrm{~g}$ dry wt $\times\left(\mathrm{mol} \mathrm{CH}_{4}\right)^{-1}$ ] of Methanobacterium thermoautotrophicum $\mathrm{Z} 245$ on $\mathrm{H}_{2} / \mathrm{CO}_{2}$.

Analytical methods. The concentrations of substrates and fermentation products were measured using HPLC and GC methods as described by Stams et al. (1993). Sulphide was measured as described by Trüper \& Schlegel (1964). Anions were analysed as described by Scholten \& Stams (1995).

\section{RESULTS AND DISCUSSION}

\section{Enrichment and isolation of strain TPO}

The enrichment of the thermophilic, syntrophic, propionate-oxidizing strain TPO from methanogenic granular sludge was described previously by Stams et al. (1992). Methanobacterium thermoautotrophicum Z245 was removed from the enrichment culture by pasteurizing the culture for $30 \mathrm{~min}$ at $90{ }^{\circ} \mathrm{C}$ and performing subsequent transfers in media with pyruvate as the carbon source. This resulted in a culture of strain TPO that was found to be pure when checked by light microscopy and on soft agar media $(0.75 \%$ agar $)$ containing pyruvate. Colonies, embedded in the soft agar, were white to brownish, lens-shaped, and reached a diameter of $0 \cdot 1-0 \cdot 2 \mathrm{~mm}$.

\section{Morphological characteristics}

Cells of strain TPO were rod-shaped, with rounded ends, and were $1 \mu \mathrm{m} \times 3-11 \mu \mathrm{m}$ in size. They occurred as single cells, but sometimes pairs were formed. When sporulation started, cells became lens-shaped, and ultimately only oval spores remained. Spores were in the centres of the cells: one spore $(1.5 \mu \mathrm{m} \times 1.5 \mu \mathrm{m})$ per cell was observed. Cells stained Gram-negative but the cell wall ultrastructure resembled that of Grampositive bacteria, as shown in Fig. 1. Weak motility was observed only in cultures growing on pyruvate.

\section{Physiological characterization and metabolism of strain TPO in pure culture and in co-culture with Methanobacterium thermoautotrophicum Z245}

Strain TPO was strictly anaerobic, since no growth occurred in the presence of traces of oxygen. The strain grew in pure culture on pyruvate at temperatures between 45 and $62{ }^{\circ} \mathrm{C}$; the optimum was $55^{\circ} \mathrm{C}$. The $\mathrm{pH}$ optimum for growth on pyruvate was $7-7 \cdot 5$. Below a $\mathrm{pH}$ of 6 and above $\mathrm{pH} 8$, no measurable growth occurred. Under optimum conditions, the growth rate of strain TPO in pure culture on pyruvate was $0.33 \mathrm{~d}^{-1}$. Yeast extract $(0.02 \%)$ stimulated growth but was not required. Besides pyruvate, lactate, fumarate, $\mathrm{H}_{2} / \mathrm{CO}_{2}$ and benzoate each supported growth of strain TPO in pure culture (Table 1).

A remarkable feature of strain TPO is its ability to grow fermentatively on benzoate. In methanogenic environments, benzoate is generally oxidized to acetate and $\mathrm{H}_{2}$. This reaction is highly unfavourable under standard conditions: $\mathrm{C}_{6} \mathrm{H}_{5} \mathrm{COO}^{-}+6 \mathrm{H}_{2} \mathrm{O} \rightarrow$ $3 \mathrm{CH}_{3} \mathrm{COO}^{-}+2 \mathrm{H}^{+}+\mathrm{CO}_{2}+3 \mathrm{H}_{2} ; \quad \Delta G^{0^{\prime}}=+49 \cdot 5 \mathrm{~kJ}$ benzoate $\mathrm{mol}^{-1}\left(\Delta G^{0^{\prime}}\right.$ values were taken from Thauer et al., 1977). However, strain TPO does not produce 3 mol hydrogen from benzoate (Table 2). Only traces of hydrogen could be measured. Since the fermentation balance on benzoate is far from complete, an unknown reduced end-product must have been formed during its conversion. We speculate that the strain is able to reduce the aromatic ring, probably to cyclohexane carboxylate or cyclohexene carboxylate, in a manner similar to that described as occurring in anaerobic sludge (Kleerebezem, 1999). Elshahed et al. (2001) very recently proposed that benzoate oxidation by a syntrophic co-culture of 'Syntrophus aciditrophicus' strain SB and Methanospirillum hungatei occurs via the intermediate formation of cyclohexane carboxylate and cyclohexene carboxylate (or their coenzyme A derivatives). Research is in progress to reveal the identity of the unknown compound(s) formed from benzoate fermentation by strain TPO.

In addition, the bacterium was able slowly to ferment glycine to acetate. Glycine is probably first converted via a glycine decarboxylase complex. The 'methylene' group formed may enter the homoacetogenic pathway, resulting in the formation of acetate.

In co-culture with Methanobacterium thermoautotrophicum strain Z245, strain TPO was able to utilize the following compounds: propionate, pyruvate, lactate, fumarate and benzoate. Fig. 2 shows the stoichiometry of propionate utilization by strain TPO in 

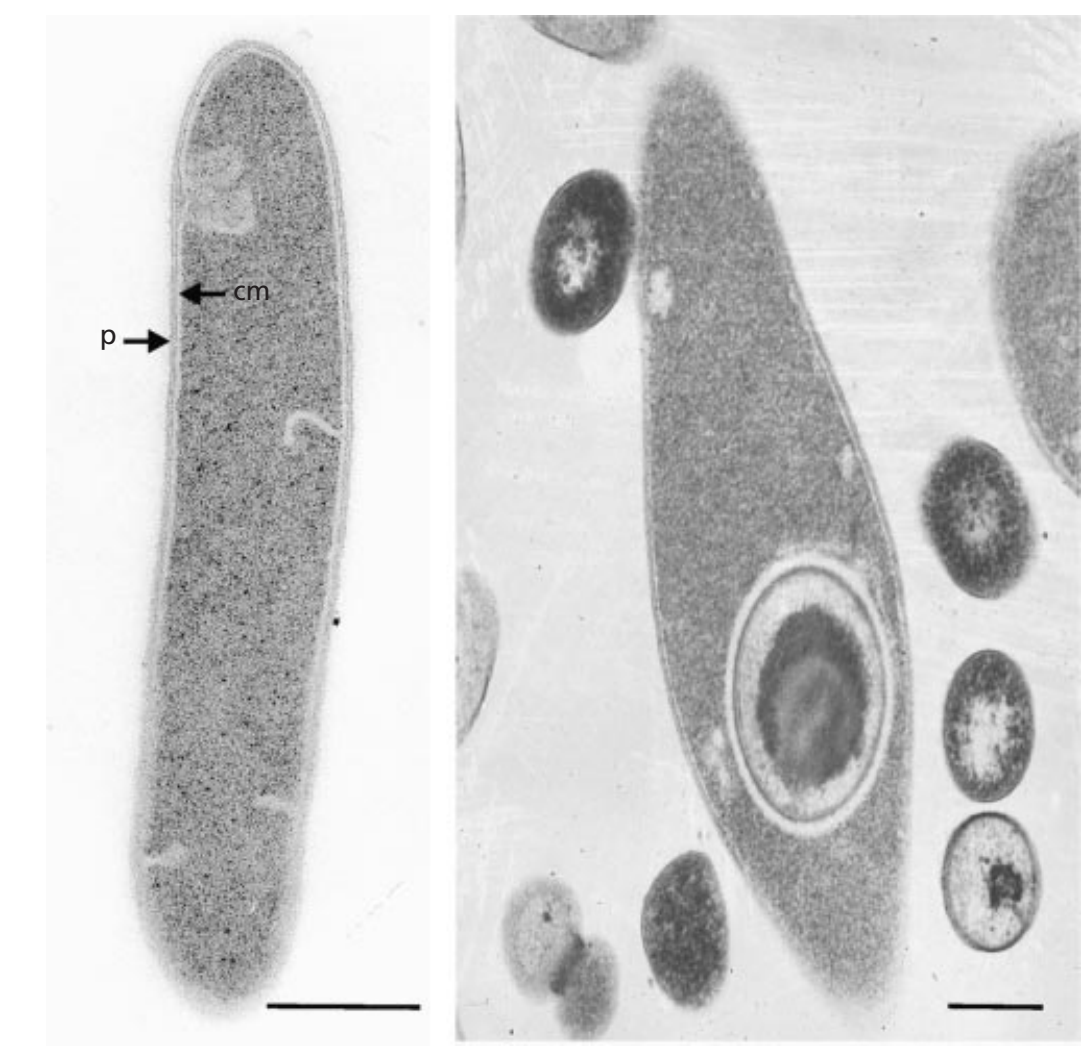

Fig. 1. Electron micrographs showing (left) the general morphology of strain TPO and the single-layered structure of the cell wall $(\mathrm{cm}$, cytoplasmic membrane; $p$, peptidoglycan layer) and (right) spore formation. The culture was grown on propionate in the presence of Methanobacterium thermoautotrophicum Z245. Bars, $0.5 \mu \mathrm{m}$.

Table 1. Growth rates and optical density $\left(\mathrm{OD}_{600}\right)$ measurements of strain TPO grown under different conditions

\begin{tabular}{|c|c|c|c|}
\hline Substrate $\left(\mathrm{mmol} \mathrm{l}^{-1}\right)$ & Products $\left(m m o l ~ l^{-1}\right)$ & Growth rate $\left(d^{-1}\right)$ & $\mathrm{OD}_{600}$ \\
\hline Pyruvate $(15 \cdot 0)$ & Acetate $(16 \cdot 0)$ and $\mathrm{H}_{2}(0 \cdot 3)$ & $0 \cdot 33$ & 0.067 \\
\hline Fumarate (18.9) & $\begin{array}{l}\text { Succinate }(13 \cdot 9) \text {, acetate }(4 \cdot 0), \\
\text { propionate }(1 \cdot 4) \text { and } \mathrm{H}_{2}(0 \cdot 065)\end{array}$ & $0 \cdot 247$ & $0 \cdot 114$ \\
\hline Lactate $(12 \cdot 4)$ & Acetate $(11 \cdot 3)$ and $\mathrm{H}_{2}(0 \cdot 15)$ & $0 \cdot 138$ & 0.039 \\
\hline Propionate $(7 \cdot 8)+\mathrm{SO}_{4}^{2-}(20)$ & Acetate $(6 \cdot 8), \mathrm{HS}^{-}(4 \cdot 1)$ & 0.099 & $0 \cdot 060$ \\
\hline Benzoate (10) & $\begin{array}{l}\text { Acetate }(13) \text {, propionate }(0 \cdot 5) \\
\text { and succinate }(1 \cdot 5)\end{array}$ & ND & $\mathrm{ND}$ \\
\hline $\mathrm{H}_{2} / \mathrm{CO}_{2}\left(10^{5} \mathrm{~Pa}\right)$ & Acetate $(9 \cdot 7)$ & ND & ND \\
\hline $\begin{array}{l}\text { Propionate }(18 \cdot 0)+ \\
\text { Methanobacterium } \\
\text { thermoautotrophicum Z245 }\end{array}$ & Acetate (18.9), $\mathrm{CH}_{4}(14 \cdot 1)$ & $0 \cdot 115$ & $0 \cdot 144$ \\
\hline
\end{tabular}

ND, Not determined.

the presence of the methanogen Methanobacterium thermoautotrophicum Z245. In co-culture, malate, alanine and glycine were also slowly converted.

The following single substrates were tested and found not to be utilized for growth either by the pure culture or by the co-culture with strain TPO: glucose, fructose, ribose, sucrose, xylose, xylitol, acetate $(10 \mathrm{mM})$, citrate $(10 \mathrm{mM})$, succinate $(10 \mathrm{mM})$, butyrate, tartrate, malonate, glutamate, aspartate, methanol, ethanol, propanol $(10 \mathrm{mM})$, butanol, 2,3-butanediol $(10 \mathrm{mM})$, acetoin $(10 \mathrm{mM})$, Casamino acids $(0 \cdot 2 \%, \mathrm{w} / \mathrm{v})$, peptone $(0 \cdot 2 \%, \mathrm{w} / \mathrm{v})$.

The following Stickland mixtures did not support growth: alanine + arginine, alanine + proline, leucine + proline. In the case of glycine-containing incubations (propionate + glycine, leucine + glycine) no more acetate was formed than with glycine alone, indicating that glycine could not serve as an electron acceptor. Therefore it appeared that strain TPO was incapable of performing Stickland reactions. 
Table 2. Characteristics that differentiate strain TPO from other closely related organisms

\begin{tabular}{|c|c|c|c|c|}
\hline Characteristic & TPO & $\begin{array}{l}\text { Desulfotomaculum } \\
\text { thermobenzoicum }\end{array}$ & $\begin{array}{c}\text { Desulfotomaculum } \\
\text { thermocisternum }\end{array}$ & $\begin{array}{l}\text { Desulfotomaculum } \\
\text { thermoacetoxidans }\end{array}$ \\
\hline Gram stain & - & + & ND & - \\
\hline Cell wall structure & + & ND & + & ND \\
\hline Cell morphology & $\begin{array}{l}\text { Rod shaped with pointed } \\
\text { ends to lens-shaped }\end{array}$ & Rod-shaped & Rod-shaped & Rod-shaped with pointed ends \\
\hline Colony formation & On soft agar & On agar & On Gelrite & Prepurified agar \\
\hline Motility & Weak & Weak & + & Weak \\
\hline Spore formation & + & + & + & + \\
\hline Temperature optimum $\left({ }^{\circ} \mathrm{C}\right)$ & 55 & 62 & 62 & $55-60$ \\
\hline Temperature range $\left({ }^{\circ} \mathrm{C}\right)$ & $45-62$ & $40-70$ & $41-75$ & $45-65$ \\
\hline pH optimum & $7 \cdot 0$ & $7 \cdot 2$ & $6 \cdot 7$ & $6 \cdot 5$ \\
\hline $\mathrm{G}+\mathrm{C}$ content $(\mathrm{mol} \%)$ & $53 \cdot 7$ & $52 \cdot 8$ & $56-57$ & $49 \cdot 7$ \\
\hline Fermentative growth & $\begin{array}{c}\text { Pyruvate, lactate, fumarate, } \\
\text { glycine, benzoate }\end{array}$ & Pyruvate, lactate & Pyruvate & Pyruvate \\
\hline $\begin{array}{l}\text { Substrate oxidation coupled } \\
\text { to sulphate reduction }\end{array}$ & Incomplete & Complete & Incomplete & Complete \\
\hline \multicolumn{5}{|l|}{ Other electron acceptors: } \\
\hline $\mathrm{SO}_{3}^{2-}$ & - & + & + & - \\
\hline $\mathrm{S}_{2} \mathrm{O}_{3}^{2-}$ & - & + & + & + \\
\hline $\mathrm{S}^{0}$ & ND & - & - & - \\
\hline $\mathrm{NO}_{3}^{-}$ & - & + & & - \\
\hline $\begin{array}{l}\text { Syntrophic growth } \\
\text { on propionate }\end{array}$ & + & - & $-{ }^{*}$ & - \\
\hline
\end{tabular}

ND, Not determined.

* Nilsen et al. (1996) reported syntrophic growth on propionate by D. thermocisternum. However, we could not reproduce these results, nor could Imachi et al. (2000).

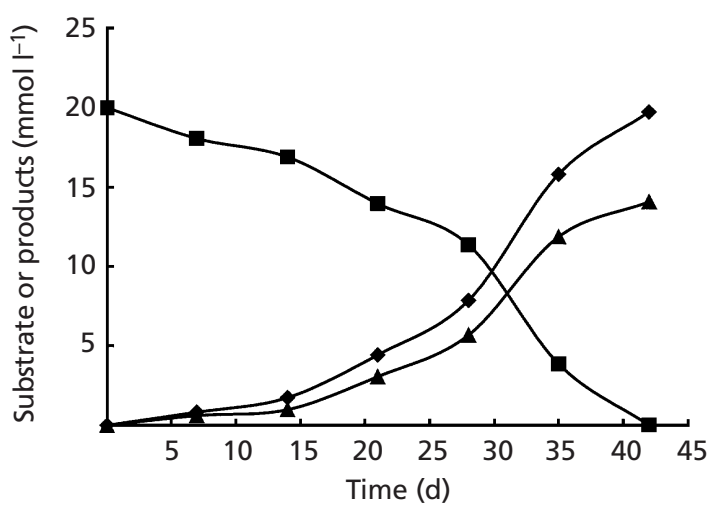

Fig. 2. Propionate degradation $(\boldsymbol{\square})$ and formation of acetate $(\boldsymbol{\Delta})$ and methane $(\boldsymbol{\Delta})$ by strain TPO in co-culture with Methanobacterium thermoautotrophicum strain Z245 measured over time.

Sulphate was able to serve as the electron acceptor for growth on propionate, lactate, pyruvate and $\mathrm{H}_{2} / \mathrm{CO}_{2}$. Acetate was formed as the end-product. Acetate could not be used by strain TPO in the presence of sulphate. The presence of sulphate had no effect on the fermentation of fumarate and benzoate.
Thiosulphate, sulphite, nitrate and fumarate could not be utilized as electron acceptors for propionate oxidation. When strain TPO was cultivated in the presence of propionate + fumarate, fumarate was fermented (Table 1).

Specific enzyme activities measured in cell-free extracts varied in different cell preparations. The lysozyme treatment followed by ultrasonic treatment resulted in extracts with the highest activity. Results of the measurements with cells grown in co-culture with Methanobacterium thermoautotrophicum strain Z245 on propionate and in pure culture on $\mathrm{H}_{2} / \mathrm{CO}_{2}$ + sulphate are shown in Table 3. Enzymes from the methylmalonyl-CoA pathway of propionate conversion were present at high to moderately high activities in cell extracts of propionate-grown cells. Extracts from cells grown with $\mathrm{H}_{2}+\mathrm{SO}_{4}^{2-}$ showed moderately high activities of carbon monoxide dehydrogenase, whereas no 2-oxoglutarate dehydrogenase activity could be detected, indicating the presence of the acetylCoA pathway during autotrophic growth.

\section{Phylogeny and $\mathbf{G}+\mathrm{C}$ content}

A total of $1551 \mathrm{bp}$ of the 16S rDNA gene from strain TPO were sequenced. To determine the phylogenetic position of strain TPO, we compared the data with 
Table 3. Enzyme activities in cell-free extracts of strain TPO

Data are for strain TPO grown on propionate in co-culture with Methanobacterium thermoautotrophicum $\mathrm{Z} 245$ and on $\mathrm{H}_{2} / \mathrm{CO}_{2}$ plus sulphate in pure culture. Activities are expressed

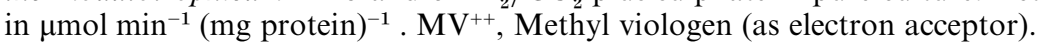

\begin{tabular}{|c|c|c|}
\hline Enzyme & Propionate* & $\mathrm{H}_{2} / \mathrm{CO}_{2}+$ sulphate \\
\hline Propionate kinase & $0 \cdot 93$ & \\
\hline Methylmalonyl CoA:pyruvate transcarboxylase & $0 \cdot 56$ & \\
\hline Succinate dehydrogenase & $<0 \cdot 001$ & \\
\hline Fumarase (disappearance of fumarate) & $4 \cdot 8$ & \\
\hline Fumarase (formation of fumarate) & $0 \cdot 16$ & \\
\hline Malate dehydrogenase (NAD) & $0 \cdot 58$ & \\
\hline Malate dehydrogenase (NADH) & $0 \cdot 33$ & \\
\hline Pyruvate dehydrogenase $\left(\mathrm{MV}^{++}\right)$ & $1 \cdot 55$ & $0 \cdot 8$ \\
\hline Phosphotransacetylase & $1 \cdot 50$ & \\
\hline Acetate kinase & $0 \cdot 66$ & \\
\hline Hydrogenase $\left(\mathrm{MV}^{++}\right)$ & 0.96 & \\
\hline 2-Oxoglutarate dehydrogenase & ND & Not detected \\
\hline Carbon-monoxide dehydrogenase $\left(\mathrm{MV}^{++}\right)$ & ND & $0 \cdot 6-0 \cdot 7$ \\
\hline
\end{tabular}

* Activities were calculated after correction for the protein content of the methanogen (see Methods); ND, not determined.

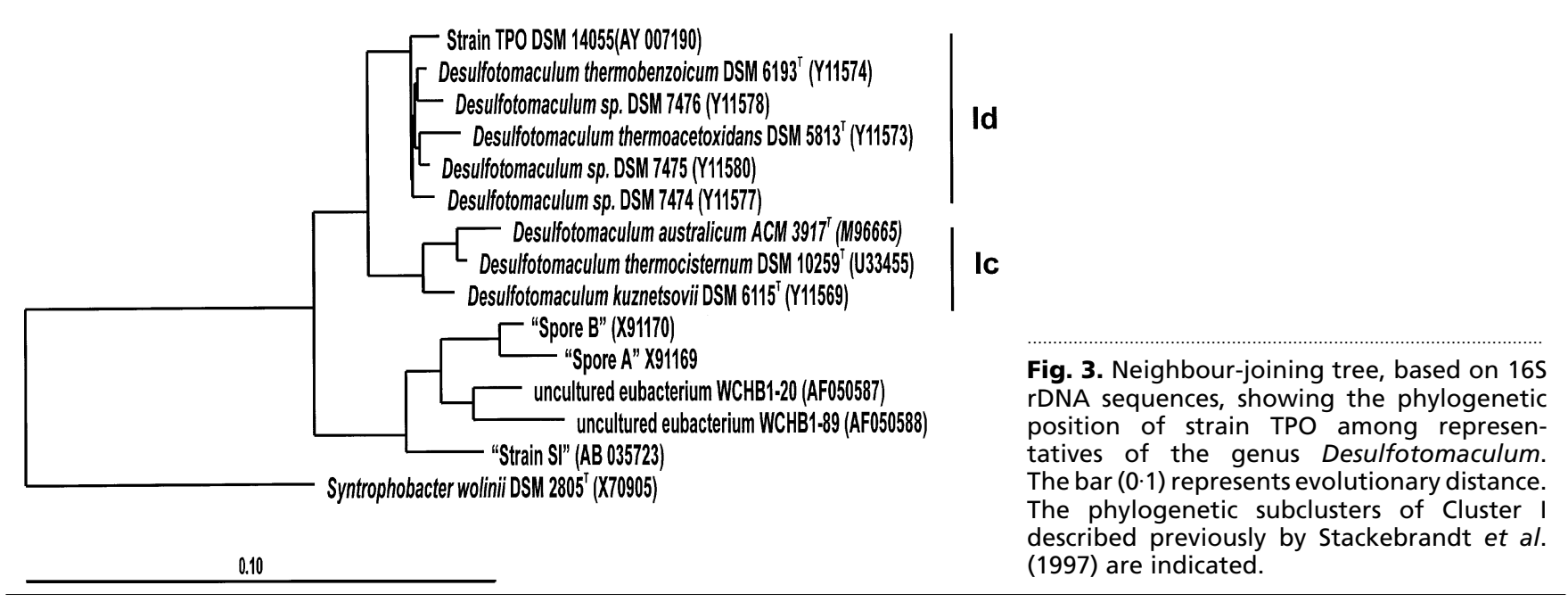

known bacterial 16S rDNA sequences (Fig. 3). Sequence analysis showed that strain TPO fell within the phylogenetic subcluster Id of the genus Desulfotomaculum, as defined by Stackebrandt et al. (1997), the closest neighbours being $D$. thermoacetoxidans (Min \& Zinder, 1990) and D. thermobenzoicum (Tasaki et al., 1991), each of which showed $98 \%$ similarity. DNA-DNA hybridization of strain TPO with $D$. thermoacetoxidans, $D$. thermobenzoicum and D. thermocisternum revealed $83 \cdot 8,88 \cdot 2$ and $43 \cdot 4 \%$ reassociation values, respectively. The $\mathrm{G}+\mathrm{C}$ content of strain TPO was $53.7 \mathrm{~mol} \%$.

\section{Comparison of strain TPO with related strains}

Thus far, there is no detailed description of other thermophilic propionate-oxidizing syntrophs from anaerobic environments. Only D. thermocisternum
(Nilsen et al., 1996) was described as growing syntrophically on propionate in the presence of Methanococcus thermolithotrophicus (DSM 8766). However, no details were given concerning the stoichiometry and propionate-conversion rates.

$D$. thermobenzoicum, D. thermoacetoxidans and $D$. thermocisternum were all pregrown on propionate + sulphate. These cells were used as the inocula to construct syntrophic consortia with Methanobacterium thermoautotrophicum Z245 to degrade propionate. After $60 \mathrm{~d}$ incubation, neither substantial methane production nor disappearance of propionate could be detected. Experiments were also carried out in the presence of $2 \mathrm{mM}$ sulphate, to stimulate the organisms. Furthermore, the organisms were incubated at their optimum growth temperatures (Table 2). In all cases propionate was depleted to a level just 
sufficient to reduce all the sulphate present. Thereafter, no further propionate degradation could be measured. A third trial was done and, in this case, besides $2 \mathrm{mM}$ sulphate, $0.2 \mathrm{mM} \mathrm{FeCl}_{2}$ was also added to the cultures. The addition of $\mathrm{FeCl}_{2}$ leads to the formation of $\mathrm{FeS}$ precipitates, to which many bacteria can adhere (Stams et al., 1992), and brings the acetogenic and methanogenic organisms into closer contact with each other. An additional advantage is that the methanogens remain viable over a much longer period of time. These conditions did not result in measurable propionate degradation after $60 \mathrm{~d}$ incubation either. Imachi et al. (2000) were also unsuccessful in growing $D$. thermocisternum in a syntrophic co-culture on propionate. They used Methanobacterium thermoautotrophicum strain $\Delta \mathrm{H}$ and a Methanobacterium thermoformicicum strain as the syntrophic partner. The ability to grow syntrophically on propionate separates strain TPO from members of the Id subclass of the genus Desulfotomaculum.

The physiological differences between the Desulfotomaculum species mentioned and strain TPO are considerable (Table 2). Substrate oxidation coupled to sulphate reduction of $D$. thermoacetoxidans and $D$. thermobenzoicum is complete to $\mathrm{CO}_{2}$. Strain TPO cannot oxidize substrates further than acetate when sulphate is present. Like $D$. thermoacetoxidans and $D$. thermobenzoicum, strain TPO is capable of autotrophic growth on $\mathrm{H}_{2} / \mathrm{CO}_{2}$, forming acetate. This is confirmed by the presence of carbon monooxide dehydrogenase activity in cell-free extracts of strain TPO grown in $\mathrm{H}_{2} / \mathrm{CO}_{2}+$ sulphate (Table 3 ). Strain TPO can use only sulphate as an electron acceptor, whereas $D$. thermoacetoxidans and $D$. thermobenzoicum can also use thiosulphate. D. thermobenzoicum can also use sulphite and nitrate.

\section{Comparison of strain TPO with other syntrophic organisms}

The phylogenetic tree in Fig. 3 shows that strain TPO is distantly related to the mesophilic spore-forming propionate-oxidizing enrichment 'Spore A' and 'Spore B' (Harmsen et al., 1996) and strain SI (Imachi et al. 2000). These organisms are unable to use sulphate as a terminal electron acceptor, although they group within the Desulfotomaculum genus. They form a new cluster between clusters Ia and If as defined by Stackebrandt et al. (1997). Further comparison with these cultures is not possible because of their limited physiological description.

Physiologically, strain TPO has similarities with almost all other mesophilic, non-sporulating, syntrophic propionate-oxidizers. The ability to use sulphate as a terminal electron acceptor is a characteristic that strain TPO shares with other mesophilic, nonsporulating, syntrophic, propionate-oxidizers (Wallrabenstein et al., 1995; Van Kuijk \& Stams, 1995). On the basis of the enzyme measurements shown in Table 3 , it seems that strain TPO uses the methylmalonyl-
CoA pathway for syntrophic propionate oxidation. This pathway is used by most mesophilic, syntrophic propionate-oxidizers (Houwen et al., 1990; Plugge et al., 1993; Wallrabenstein et al., 1995). Smithella propionica (Liu et al., 1999) has a different stoichiometry for propionate conversion with respect to strain TPO. It forms acetate as well as butyrate as organic end-products from propionate conversion. Smithella propionica can grow on crotonate in pure culture, but cannot use sulphate as the terminal electron acceptor.

Strain TPO is phylogenetically different from previously described propionate-degrading bacteria (Fig. $3)$.

On the basis of the differences between strain TPO and known organisms, we propose to designate strain TPO as a new subspecies of $D$. thermobenzoicum, namely Desulfotomaculum thermobenzoicum subsp. thermosyntrophicum subsp. nov. This automatically creates Desulfotomaculum thermobenzoicum subsp. thermobenzoicum subsp. nov.

\section{Emended description of Desulfotomaculum thermobenzoicum Tasaki et al. 1991}

Desulfotomaculum thermobenzoicum (thermo.ben.zo'i. cum. Gr. adj. thermos hot; N.L. gen. n. benzoicum pertaining to benzoate; Desulfotomaculum thermobenzoicum a sausage-shaped organism that reduces sulphur compounds and oxidizes benzoate under anaerobic conditions).

Rod-shaped Gram-positive cells 1·0-2 $\mu \mathrm{m} \times 3-11 \mu \mathrm{m}$ in size with pointed ends, single or in pairs. Sporeforming and slightly motile. Strictly anaerobic, moderately thermophilic and neutrophilic. The substrates used coupled to sulphate reduction are lactate, pyruvate, propionate and $\mathrm{H}_{2} / \mathrm{CO}_{2}$. Acetate is not oxidized. Pyruvate and lactate are degraded without sulphate. Grows at $40-70{ }^{\circ} \mathrm{C}$ and $\mathrm{pH}$ 6-8; optimum conditions are at $55-62{ }^{\circ} \mathrm{C}$ and $\mathrm{pH} 7 \cdot 0-7 \cdot 2$. Desulfoviridin is not present. The DNA $\mathrm{G}+\mathrm{C}$ content is $52.8-53.7 \mathrm{~mol} \%$. Isolated from thermophilic methanogenic reactors. The type strain is DSM $6193^{\mathrm{T}}(=$ ATCC $49756^{\mathrm{T}}$ ).

\section{Description of Desulfotomaculum thermobenzoicum subsp. thermobenzoicum subsp. nov.}

Desulfotomaculum thermobenzoicum subsp. thermobenzoicum (ther.mo.ben.zo'i.cum. Gr. adj. thermos hot; N.L. gen. n. benzoicum pertaining to benzoate; Desulfotomaculum thermobenzoicum a sausage-shaped organism that reduces sulphur compounds and oxidizes benzoate under anaerobic conditions).

Rod-shaped Gram-positive cells $1 \cdot 5-2 \mu \mathrm{m} \times 5-8 \mu \mathrm{m}$ with pointed ends, single or in pairs. Spore-forming and slightly motile. Strictly anaerobic, moderately thermophilic and neutrophilic. The substrates used coupled to sulphate reduction are benzoate, $\mathrm{H}_{2} / \mathrm{CO}_{2}$, 
formate, propionate, butyrate, valerate, caproate, ethanol, propanol, butanol, 1,2-propanediol, 1,3-propanediol, crotonate, lactate, pyruvate, fumarate and malate. Acetate is not oxidized. Pyruvate and lactate are degraded without sulphate. Grows well on benzoate, alcohols, butyrate and $\mathrm{H}_{2}+\mathrm{CO}_{2}$. Electron acceptors are sulphate, sulphite, thiosulphate and nitrate. Organic supplements (yeast extract) are required for growth. Grows at $40-70{ }^{\circ} \mathrm{C}$ and $\mathrm{pH} 6-8$; optimum conditions are at $62{ }^{\circ} \mathrm{C}$ and $\mathrm{pH} 7 \cdot 2$. Desulfoviridin is not present. The DNA G+C content is $52 \mathrm{~mol} \%$. Isolated from a thermophilic methane fermentation reactor treating kraft-pulp waste water. The type strain is DSM $6193^{\mathrm{T}}\left(=\right.$ ATCC $\left.49756^{\mathrm{T}}\right)$.

\section{Description of Desulfotomaculum thermobenzoicum subsp. thermosyntrophicum subsp. nov.}

Desulfotomaculum thermobenzoicum subsp. thermosyntrophicum (ther.mo.syn.tro'phi.cum. Gr. adj. thermos hot; Gr. pref. syn together; Gr. v. trephein to eat; syntrophos nourished together; N.L. adj. thermosyntrophicum referring to the capacity of the organism to grow at elevated temperatures on propionate in the presence of a partner organism).

Spore-forming, Gram-positive rods with pointed ends and $1.0 \times 3-11 \mu \mathrm{m}$ in size. Weakly motile, strictly anaerobic, moderately thermophilic, neutrophilic. The substrates used coupled to sulphate reduction are propionate, lactate, pyruvate and $\mathrm{H}_{2} / \mathrm{CO}_{2}$. Ferments pyruvate, lactate, fumarate, glycine and benzoate. $\mathrm{H}_{2}+\mathrm{CO}_{2}$ is converted to acetate. No organic supplements are required for growth, but yeast extract $(0.02 \%)$ enhances growth. Grows syntrophically on propionate with Methanobacterium thermoautotrophicum Z245. Grows at $45-62{ }^{\circ} \mathrm{C}$ and $\mathrm{pH}$ 6-8; optimum conditions are at $55^{\circ} \mathrm{C}$ and $\mathrm{pH}$ 7. The DNA $\mathrm{G}+\mathrm{C}$ content is $52.8 \mathrm{~mol} \%$. Isolated from thermophilic granular methanogenic sludge. Strain TPO is deposited at the DSMZ as DSM $14055^{\mathrm{T}}$.

\section{ACKNOWLEDGEMENTS}

The authors would like to thank Erwin G. Zoetendal for his help with the construction of the phylogenetic tree. The $\mathrm{G}+\mathrm{C}$ analysis by $\mathrm{Dr} \mathrm{A}$. Lysenko at the Institute of Microbiology of the Russian Academy of Sciences in Moscow was greatly appreciated.

\section{REFERENCES}

Aceti, D. J. \& Ferry, J. G. (1988). Purification and characterization of acetate kinase from acetate-grown Methanosarcina thermophila. J Biol Chem 263, 15444-15448.

Boone, D. R. \& Bryant, M. P. (1980). Propionate-degrading bacterium Syntrophobacter wolinii sp. nov., gen. nov., from methanogenic ecosystems. Appl Environ Microbiol 40, 626-632.

Bradford, M. M. (1976). A rapid and sensitive method for the quantitation of microgram quantities of protein utilizing the principle of protein-dye binding. Anal Biochem 72, 248-254.

Cashion, P., Holder-Franklin, M. A., McCully, J. \& Franklin, M. (1977). A rapid method for the base ratio determination of bacterial DNA. Anal Biochem 81, 461-466.
DeLey, J., Cattoir, H. \& Reynaerts, A. (1970). The quantitative measurement of DNA hybridization from renaturation rates. Eur $J$ Biochem 12, 133-142.

Elshahed, M. S., Bhupathiraju, V. K., Wofford, N. Q., Nanny, M. A. \& Mclnerney, M. J. (2001). Metabolism of benzoate, cyclo-1-ene carboxylate, and cyclohexane carboxylate by "Syntrophus aciditrophicus" strain SB in syntrophic association with $\mathrm{H}_{2}$-using microorganisms. Appl Environ Microbiol 67, 1728-1738.

Escara, J. F. \& Hutton, J. R. (1980). Thermal stability and renaturation of DNA in dimethylsulfoxide solutions: acceleration of renaturation rates. Biopolymers 19, 1315-1327.

Felsenstein, J. (1982). Numerical methods for inferring evolutionary trees. Q Rev Biol 57, 379-404.

Harmsen, H. J. M., Akkermans, A. D. L., de Vos, W. M. \& Stams, A. J. M. (1996). Enrichment and phylogenetic analysis of sporeforming syntrophic propionate-oxidizing bacteria. In Enrichment and phylogenetic analysis of sporeforming syntrophic propionate-oxidizing bacteria, pp. 47-60. PhD thesis, Wageningen Agricultural University.

Harmsen, H. J. M., van Kuijk, B. L. M., Plugge, C. M., Akkermans, A. D. L., de Vos, W. M. \& Stams, A. J. M. (1998). Syntrophobacter fumaroxidans sp. nov., a syntrophic propionate-degrading sulfatereducing bacterium. Int J Syst Bacteriol 48, 1383-1387.

Houwen, F.P., Plokker, J., Stams, A. J. M. \& Zehnder, A. J. B. (1990). Enzymatic evidence for involvement of the methylmalonylCoA pathway in propionate oxidation by Syntrophobacter wolinii. Arch Microbiol 155, 52-55.

Huß, V. A. R., Festl, H. \& Schleifer, K.-H. (1983). Studies on the spectrophotometric determination of DNA hybridization from renaturation rates. Syst Appl Microbiol 4, 184-192.

Imachi, H., Sekiguchi, Y., Kamagata, Y., Ohashi, A. \& Harada, H. (2000). Cultivation and in situ detection of a thermophilic bacterium capable of oxidizing propionate in syntrophic association with hydrogenotrophic methanogens in a thermophilic methanogenic granular sludge. Appl Environ Microbiol 66, 3608-3615.

Jahnke, K.-D. (1992). BASIC computer program for evaluation of spectroscopic DNA renaturation data from GILFORD SYSTEM 2600 spectrometer on a PC/XT/AT type personal computer. J Microbiol Methods 15, 61-73.

Kleerebezem, R. (1999). Anaerobic treatment of phthalates; microbiological and technological aspects. $\mathrm{PhD}$ thesis: Wageningen University.

Lane, D. J. (1991). 16S/23S rDNA sequencing. In Nucleic Acid Techniques in Bacterial Systematics, pp. 115-175. Edited by E. Stackebrandt \& M. Goodfellow. Chichester: Wiley.

Liu, Y., Balkwill, D. L., Aldrich, H. C., Drake, G. R. \& Boone, D. R. (1999). Characterisation of the anaerobic propionate-degrading syntrophs Smithella propionica gen. nov, sp. nov. and Syntrophobacter wolinii. Int J Syst Bacteriol 49, 545-556.

Marmur, J. (1961). Procedure for the isolation of desoxyribonucleic acid from microorganisms. J Mol Biol 3, 208-218.

Min, H. \& Zinder, S. H. (1990). Isolation and characterization of a thermophilic sulfate-reducing bacterium Desulfotomaculum thermoacetoxidans sp. nov. Arch Microbiol 153, 399-404.

Nilsen, R. K., Torsvik, T. \& Lien, T. (1996). Desulfotomacum thermocisternum sp. nov., a sulfate reducer isolated from hot North Sea oil reservoir. Int J Syst Bacteriol 46, 397-402.

Nübel, U., Engelen, B., Felske, A., Snaidr, J., Wieshuber, A., Amann, R. I., Ludwig, W. \& Backhaus, H. (1996). Sequence heterogeneities of genes encoding 16S rRNAs in Paenibacillus polymyxa detected by temperature gradient gel electrophoresis. J Bacteriol 178, 5636-5643.

Odom, J. M. \& Peck, H. D. (1981). Localization of dehydrogenases, reductases, and electron transfer components in the sulfate-reducing bacterium Desulfovibrio gigas. J Bacteriol 147, 161-169.

Owen, R. J., Hill, R. L. \& Lapage, S. P. (1969). Determination of DNA base composition from melting profiles in dilute buffers. Biopolymers $\mathbf{7}$, 503-516. 
Plugge, C. M., Dijkema, C. \& Stams, A. J. M. (1993). Acetyl-CoA cleavage pathway in a syntrophic propionate-oxidizing bacterium growing on fumarate in the absence of methanogens. FEMS Microbiol Lett 110, 71-76.

Plugge, C. M., Zoetendal, E. G. \& Stams, A. J. M. (2000). Caloramator coolhaasii sp. nov., a glutamate-degrading, moderately thermophilic anaerobe. Int J Syst Evol Microbiol 50, 1155-1162.

Schauder, R., Eikmanns, B., Thauer, R. K., Widdel, F. \& Fuchs, G. (1986). Acetate oxidation to $\mathrm{CO}_{2}$ in anaerobic bacteria via a novel pathway not involving reactions of the citric acid cycle. Arch Microbiol 151, 84-89.

Schink, B. (1997). Energetics of syntrophic cooperation in methanogenic degradation. Micriobiol Mol Biol Rev 61, 262-280.

Scholten, J. C. M. \& Stams, A. J. M. (1995). The effect of sulfate and nitrate on methane formation in a freshwater sediment. Antonie Leeuwenhoek 68, 309-315.

Stackebrandt, E., Sproer, C., Rainey, F. A., Burghardt, J., Päuker, O. \& Hippe, H. (1997). Phylogenetic analysis of the genus Desulfotomaculum: evidence for the misclassification of Desulfotomaculum guttoideum and description of Desulfotomaculum orientis as Desulfosporosinus orientis gen. nov., comb. nov. Int J Syst Bacteriol 47, 1134-1139.

Stams, A. J. M. (1994). Metabolic interactions in between anaerobic bacteria in methanogenic environments. Antonie Leeuwenhoek 66, 271-294.

Stams, A. J. M., Kremer, D. R., Nicolay, K., Weenk, G. H. \& Hansen, T. A. (1984). Pathway of propionate formation in Desulfobulbus propionicus. Arch Microbiol 139, 167-173.

Stams, A. J. M., Grolle, K. C. F., Frijters, C. T. M. \& Van Lier, J. B. (1992). Enrichment of thermophilic propionate-oxidizing bacteria in syntrophy with Methanobacterium thermoautotrophicum or Methanobacterium thermoformicicum. Appl Environ Microbiol 58, 346-352.

Stams, A. J. M., van Dijk, J. B., Dijkema, C. \& Plugge, C. M. (1993). Growth of syntrophic propionate-oxidizing bacteria with fumarate in the absence of methanogenic bacteria. Appl Environ Microbiol 59, 1114-1119.
Strunk, O. \& Ludwig, W. (1991). ARB: a software environment for sequence data. Department of Microbiology, Technical University of Munich, Munich, Germany (e-mail: ARB@micro.biologie. tu-muenchen.de).

Tasaki, M., Kamagata, Y., Nakamura, K. \& Mikami, E. (1991). Isolation and characterization of a thermophilic benzoate-degrading, sulfate-reducing bacterium, Desulfotomaculum thermobenzoicum sp. nov. Arch Microbiol 155, 348-352.

Thauer, R. K., Jungermann, K. \& Decker, K. (1977). Energy conservation in chemotrophic anaerobic bacteria. Bacteriol Rev 41, 100-180.

Trüper, H. G. \& Schlegel, H. G. (1964). Sulphur metabolism in Thiorhodaceae. I. Quantitative measurements of growing cells of Chromatium okenii. Antonie Leeuwenhoek 30, 225-238.

Van Kuijk, B. L. M. \& Stams, A. J. M. (1995). Sulfate reduction by a syntrophic propionate-oxidizing bacterium. Antonie Leeuwenhoek $\mathbf{6 8}$, 293-296.

Wallrabenstein, C., Hauschild, E. \& Schink, B. (1995). Syntrophobacter pfennigii sp. nov., a new syntrophically propionate-oxidizing anaerobe growing in pure culture with propionate and sulfate. Arch Microbiol 164, 346-352

Wofford, N. Q., Beaty, P. S. \& McInerney, M. J. (1986). Preparation of cell-free extracts and the enzymes involved in fatty acid metabolism in Syntrophomonas wolfei. J Bacteriol 167, 179-185.

Zehnder, A. J. B. (1978). Ecology of methane formation. In Water Pollution Microbiology, pp. 349-376. Edited by R. Mitchell. New York: Wiley.

Zeikus, J. G. (1983). Metabolic communications between biodegradative populations in nature. In Microbes in their Natural Environment, pp. 423-462. Edited by J. H. Slater \& J. W. Wittenburg. Cambridge: Cambridge University Press.

Zoetendal, E. G., Akkermans, A. D. L. \& de Vos, W. M. (1998). Temperature gradient gel electrophoresis from human fecal samples reveals stable and host-specific communities of bacteria. Appl Environ Microbiol 64, 3854-3859. 